\title{
Forging a Kiwi Economic Identity through Economic Transformation
}

\author{
Trevor Mallard
}

\section{Introduction}

This paper sets out in detail what the government's thinking is around its economic transformation agenda, where it comes from, and where we are going with it. ${ }^{1}$ First, I discuss the need for policy prescriptions to reflect a distinct Kiwi economic identity. I then discuss the government's vision of economic transformation, before reflecting on the policy agenda and the need for effective partnerships to contribute to success.

\section{Forging a Kiwi economic identity}

In 1999 the Labour-led coalition government inherited an economy that had been shaped by a firm belief in the Washington consensus, which held that economic growth prospered only when a particular set of neo-liberal policy prescriptions were followed. ${ }^{2}$ Over the last seven years, however, the government has sought to redress the failures of the more narrow and rigid elements of these policies. It is not enough simply to rely on property rights, fiscal stability and non-corrupt institutions - some South American economies are testament to what can happen, or what fails to happen, if such a narrow approach to economic policy is taken. The East Asian, Irish and Scandinavian economies, on the other hand, show what smart policies can achieve (Rodrik, 2006).

Just as there is no single set of rules that needs to be followed, it is also clear that there is no single destination or criterion for what might constitute success. Despite globalisation and the freer flow of capital, finance,

1 This paper is based on a number of key documents, including two Cabinet papers that outline the government's economic transformation agenda, plus a series of reviews of business assistance programmes.

2 Some of these policy prescriptions, such as fiscal discipline, protection of property rights and market-determined interest and exchange rates, have become uncontroversial as time has gone on. Others, like an emphasis on flat taxes, excessive deregulation, wholesale privatisation and the removal of the state from any role in economic and industry development, have been discredited by experience. technology and labour, economies succeed by doing widely different things (World Bank, 2005). This is comforting for three reasons.

- If the globalisation race was all about who can do the next big thing best, New Zealand would start at a competitive disadvantage given its small size, limited capital base and distance from markets. Indeed, the International Monetary Fund has suggested that up to half of the gap between our growth rate and the OECD average can be attributed to our country being small and far from the world's major markets (IMF, 2005).

- We can be proud of the fact that we can and should do it the Kiwi way when it comes to transforming our economy and lifting people's incomes. We have an abundant natural resource base, we have a hugely innovative culture, and, with a carefully managed environment, we can continue to produce even higher quality primary and biologically-based products thanks to know-how that has been built up over the last 150 years (Smith, 2006).

- Nurturing our national economic personality complements another of the government's key priorities, namely celebrating our national identity. With hindsight it is remarkable that anyone really thought that merely copying the standard economic development prescription for an economy that is distinct from nearly all of the world's developed economies would deliver the growth outcomes New Zealanders want.

None of this means that we can be complacent or that we can simply return to the things we did in the past. No one wants to return New Zealand to being a fortress economy strangled by an overzealous government getting in the way of business. 


\section{Table I: The government's vision for economic transformation}

The New Zealand of the future will exhibit higher productivity and be a more active participant in the global economy, with higher levels of exports and more investment links with the rest of the world.

We will have firms and industries that are smarter in their use of the resources they have, delivering innovative and high-value products and services for businesses and consumers around the world.

Our nation will be fully hooked into the latest technology, ideas, knowledge and market trends through world-class infrastructure, higher levels of investment in science and technology, and strong people-to-people connections.

We will have more globally competitive firms that are nimble, creative and innovative, invest more in science and technology, and link into domestic and global value chains.

We will have a strong, vibrant primary sector and innovative biologically-based industries, and use our natural resources, including those belonging to Māori, efficiently and wisely for maximum long-term effect.

We will also have more high-value upstream and downstream spin-off industries that leverage off our strengths and continue to diversify through the emergence and development of new areas of strength, as we have seen occur in tourism, the screen industry and international education.

Our firms will benefit more from the country's focus on enhancing its natural environment and effective management of the resource base, through both market positioning and new technologies.

New Zealand's people will invest in acquiring new knowledge and skills and these will be effectively applied in the workforce to create ideas and capitalise on them.

Auckland will be an internationally competitive city that has fit-for-purpose infrastructure, is a launch pad for our businesses to internationalise, is New Zealand's gateway to the world, has effective governance, and has strong connections with the rest of the country.

As a country, we will take full advantage of our regional positioning, with greater business and government collaboration with Asia and Australia, creating a seamless trans-Tasman market to seize greater benefits from scale, specialisation and cooperation.

\section{Our vision of economic transformation}

Two recently released Cabinet papers outline what the government means by economic transformation and provide an indicative, detailed action plan for addressing the critical issues for achieving this economic transformation vision. This vision is based on New Zealand's unique characteristics, the latest thinking on economic development, and lessons learnt from our key comparator countries (Easton, 2006b). Key features of this vision are summarised in Table 1.

To achieve this economic transformation vision the government is actively pursuing an agenda focusing on five key areas. These areas are: growing globally competitive firms; world-class infrastructure; innovative and productive workplaces underpinned by high standards in education, skills and research; an internationally competitive city - Auckland; and environmental sustainability. This agenda will evolve as we continue to learn more about New Zealand's circumstances and how best to respond to them.

Innovation is at the heart of our economic transformation strategy. Innovation means more than just science or research. Innovation is about creating new products and processes based on new ideas, but also through adopting and absorbing ideas and knowledge from right around the world (Lundvall, 1992). Specifically, new products and processes need to mesh with the changing tastes and values of rapidly changing global markets, leverage the opportunities that new technologies create, and respond to the competitive challenges of emerging competitors. To achieve this it is necessary to recognise that: 
- Innovation must be pervasive and occur across all industries, not just ICT, biotechnology and multimedia (Nelson and Winter, 1982; Smith, 2006).

- Innovation needs to build on previous learning, as new industries will typically develop off the back of existing strengths, particularly the primary sector and biologically-based industries (Nelson and Winter, 1982; Smith, 2006). ${ }^{3}$

- As well as continuing to support the development of new industries from our existing strengths, we need to be responsive to unexpected successes that may arise.

- We need to work in a more coherent way across government and better focus and target government resources.

As a country we also need to improve our export performance and our links with the rest of the world. We are, furthermore, reaching the limits of what we can do to get more people into work, with relatively high labour utilisation and the lowest unemployment rate in the OECD (Ministry of Eonomic Development and the Treasury, 2005). That is why we need to lift the productivity of those working if we are to catch up. Doing this is not straightforward. It involves attack across a range of fronts and sustained effort over many years.

\section{Shaping the policy agenda}

In moving forward we are listening carefully to the views of business leaders. A key message coming from the business community is the need for better targeting of efforts. It is very difficult for a small economy to take a scatter-gun approach, generating large numbers of new products in the hope that on the law of averages the odd one will hit the target. While taking a more targeted approach is inherently a riskier strategy, the pay-off is potentially much larger, particularly when managed smartly. It was this thinking that was behind the government's recent decision to provide an interestfree US $\$ 8$ million loan to support Right Hemisphere to establish and support a world-leading 3D digital content and graphics industry in New Zealand (Ministry of Economic Development, 2006). ${ }^{4}$

The government is also revamping its business assistance programmes so they better suit New Zealand's needs. As a result of a recent expenditure review of business assistance, changes will be made so that the Ministry of Economic Development will work with agencies including the Ministry of Research, Science and Technology and the Tertiary Education Commission to review funding for programmes supporting innovation, education and business partnerships between firms, crown research institutes (CRIs) and tertiary education organisations. This will ensure that priorities are more closely aligned. We will also shift the focus of existing programmes to support more explicitly international connections, innovation and investment.

We have increased funding for research, science and technology by $52 \%$ over the last six years, from $\$ 424$ million in $1999 / 2000$ to $\$ 646$ million in $2006 / 07$. Initiatives such as research consortia and centres of research excellence have forged links between researchers and industry and provide a platform for further engagement. In the future more emphasis will be placed on commercialising what comes out of our research system, and we will continue to seek ways of getting the most out of our public research organisations (MoRST, 2006). This means ensuring that our CRIs are oriented towards meeting the research needs of business and that they make good judgements about the best route to the commercialisation of their research.

Industry training funding has increased from $\$ 56$ million in 1999 to $\$ 146$ million in 2007 and is beginning to address the chronic skills shortages faced by many sectors, with more trainees and qualifications being gained by New Zealanders. In the tertiary sector our big push is to improve the relevance of education. Rather than simply churning out more students, tertiary education organisations will be funded according to negotiated three-year plans that will require them to engage with firms and respond to national and regional skill needs (TEC, 2006).

We are also encouraging state owned enterprises (SOEs) to consider expanding their scope of business. SOEs

3 This approach of adding value to the existing resource base through persistent technological upgrading of resource-based and low-tech industries is consistent with the economic development path of a number of western European economies. Denmark, for instance, which has similar natural resource and size characteristics to New Zealand, has by and large become rich by leveraging off its historical growth industries of agriculture, timber products and shipping to produce specialisations in areas such as high-value agriculture, agricultural equipment, domestic and office furniture, transport and ports, electronics and pharmaceuticals.

4 Right Hemisphere has both the scale and technology to be a cornerstone in the development of a world leading 'virtual cluster' or ecosystem of private companies, researchers, and educators in the $3 \mathrm{D}$ digital content and graphics area. 
are uniquely placed to contribute to New Zealand's economic transformation, given that they have a committed long-term owner, and that a number have significant capacity and commercial capability to diversify. This new policy environment does not, however, provide a mandate for SOEs to be frivolous with taxpayer assets (New Zealand Treasury, 2006).

Over the past six years the government has also made significant inroads into fixing this country's infrastructure. Road transport funding is increasing to $\$ 13.4$ billion over the next five years, close to a doubling in funding. A massive increase in capital expenditure on the electricity grid is planned, averaging around $\$ 470 \mathrm{~m}$ a year over the next seven years. About $1,500 \mathrm{MW}$ of new generating capacity is planned for the next five years and security margins are projected to increase. Management of dry years is improving, with far more information available through the Electricity Commission than in the past, although we still need to see further improvements.

New Zealand's environment underpins much of our economic and export activities - agriculture, horticulture, fisheries and forestry account for $67 \%$ of merchandise exports. As well as providing New Zealanders with a unique and enjoyable lifestyle, we see the environment as providing the platform for the economy now and into the future. Our firms need to be using environmental best practices and technologies. This will keep us up with international competitors and provide opportunities for new industries to develop. International developments in areas such as climate change, and local challenges to our natural resource base, have important implications for our economy. These developments and challenges provide an opportunity to implement policies to encourage New Zealand firms to develop and adopt new technologies, thus improving resource efficiency and potentially providing future competitive advantages. There are opportunities to reduce carbon emissions in a number of key sectors, including agriculture, transport and energy. A high priority of government is to prevent irreversible soil loss, enhance carbon sequestration and mitigate flood damage.

Other work under way, including the review of business taxation, refocusing of regional policy and work on Auckland governance, extension of the Market Development Assistance Scheme, and Export Year 2007 are also important steps by government to help achieve our economic transformation vision.

\section{Partnerships contributing to success}

In developing the policy approaches that will support New Zealand's economic transformation, the government does not have all the answers. The challenges facing the New Zealand economy are complex. The solutions are also complex and will ultimately rest on businesses rising to the challenge and on effective partnerships operating within the web of interests that contribute to success. To a large extent the challenge is for all New Zealanders to seize - businesses will need to drive innovation and internationalisation, and businesses must take this responsibility on board. Success also flows out of contributions from research and education providers, from the builders and operators of our infrastructure, and from the business and union engagements in raising productivity. It is driven by a shared belief in New Zealand.

It is very easy to play the 'blame and moan' game, but far more satisfying and constructive to be an active part of the solution. The Labour-led government is actively building a partnership model with business and other stakeholders to provide greater engagement and sharing of information so that, together, we can deliver New Zealand's economic transformation. The types of strategic partnerships that we are seeking are not easy to establish. Excessive fear of special pleading by business and other interests contributed to the near elimination of the government-business networks that are now commonplace in most developed economies. To rebuild these networks we have partnered with industries and regions across New Zealand and there has been some productive work through major regional initiatives and government-industry taskforces. We have made good progress in this area, but acknowledge that at times our engagement processes have been slightly 'clunky' and perhaps too high-level.

We have taken on a brokering and co-ordinating role through the economic development agency New Zealand Trade and Enterprise, as needed, to overcome information and co-ordination problems. We have partnered with the ICT, biotechnology, design, screen, wood processing, niche manufacturing, food and beverage, aquaculture, and textile, clothing and footwear sectors. Now all regions have economic development strategies and 21 major regional initiatives have been approved. Through these initiatives the private sector and the government are beginning to discover and identify what can be profitably produced, and 
establishing the right skills and infrastructure to bring about this development (Easton, 2006a). Through strategic collaboration with the private sector we have sought to uncover where the most significant obstacles lie and what type of intervention would most likely remove them or mitigate their impact.

\section{Conclusion}

When we entered government in 1999 the cupboard was remarkably bare on our knowledge of sectoral and firm performance and constraints, but we now know much more about how to create policies fit for New Zealand and its regions (see Ministry of Economic Development and the Treasury, 2005). We have, for example, a much better understanding of the difficulties New Zealand firms face when establishing offshore production, distribution and marketing networks, and the areas where government intervention can have a lasting impact (Smith, 2006). But there is much more work to be done. While New Zealand has enjoyed one of the highest growth rates in the OECD over the last five years, we need to maintain this impressive growth rate to catch up to the OECD average income per capita. Through the economic transformation agenda the government has committed itself to improving economic outcomes for all New Zealanders. As a young and nimble nation, together we can take on the world and make the most of the opportunities presented to us - and in doing so forge a unique Kiwi economy.

\section{References}

Easton, B. (2006a) 'What might New Zealand's economic transformation mean?', available at: http:// www.eastonbh.ac.nz/?p=764

Easton, B. (2006b) 'What New Zealand's economic transformation is about', available at: http://www. eastonbh.ac.nz/?p $=743$

International Monetary Fund (2005) New Zealand and the IMF, available at: http://www.imf.org/external/ country/NZL/index.htm

Lundvall, B.A. (ed) (1992) National Systems of Innovation: towards a theory of innovation and interactive learning, New York: Oxford University Press

Ministry of Economic Development (2006) 'Kiwi $3 \mathrm{D}$ industry in the frame with government support - prime minister and minister of economic development media statement', available at: http://www.med.govt. nz/templates/MultipageDocumentTOC_22256.aspx

Ministry of Economic Development and the Treasury (2005) Growth through Innovation: economic development indicators 2005, available at: http://www.treasury.govt. nz/nzeconomy/edi2005.asp

Ministry of Research, Science and Technology (MoRST) (2006) Research and Development in New Zealand: a decade in review, available at: http://www.morst.govt. $\mathrm{nz} /$ publications/statistics/decade-in-review/

Nelson, N.R. and S.G. Winter (1982) An Evolutionary Theory of Economic Change, Chicago: Belknap Press

New Zealand Treasury (2006) Treasury Report 2006/595 - SOEs as tools for promoting economic growth, available at: http://www.beehive.govt.nz/mallard/soe06/soe1. aspx?PID $=52 \& \mathrm{MID}=3$

Rodrik, D. (2006) 'Goodbye Washington consensus, hello Washington confusion?', available at: http:// ksghome.harvard.edu/-drodrik/Lessons\%20of\%20th e\%201990s\%20review\%20_JEL_.pdf

Smith, K. (2006) Public Policy Framework for the New Zealand Innovation System, available at: http://www. med.govt.nz/templates/MultipageDocumentTOC_ 23027.aspx

Tertiary Education Commission (TEC) (2006) 'Media statement: key decisions to improve tertiary performance', available at: http://www.tec.govt.nz/ downloads/a2z_publications/media-release-and-q-a-drcullen-27-jul-06-announcement.pdf

World Bank (2005) Economic Growth in the 1990s: learning from a decade of reform, available at: http:// www1.worldbank.org/prem/lessons1990s/

Trevor Mallard is the member of Parliament for Hutt South. He has been a senior Cabinet minister since 1999 and has held a range of portfolios, including education, energy and state services. $\mathrm{He}$ is currently Minister of Economic Development, Minister of Industry and Regional Development, Minister of State Owned Enterprises, Minister for Sport and Recreation and Associate Minister of Finance. 